Speaking Truths 



\title{
Speaking Truths
}

Young Adults, Identity, and Spoken Word Activism

\author{
VALERIE CHEPP
}

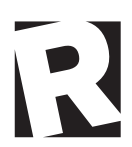

Rutgers University Press

New Brunswick, Camden, and Newark, New Jersey, and London 
Library of Congress Cataloging-in-Publication Data

Names: Chepp, Valerie, author.

Title: Speaking truths : young adults, identity, and spoken word activism / Valerie Chepp.

Description: New Brunswick : Rutgers University Press, [2022] | Includes bibliographical references and index.

Identifiers: LCCN 2021016604 | ISBN 9781978801103 (paperback) |

ISBN 9781978801110 (hardback) | ISBN 9781978801127 (epub) |

ISBN 978197880II 4I (pdf)

Subjects: LCSH: Social justice. | Youth-Political activity. | Social change.

Classification: LCC HM671 .C479 2022 | DDC 303.3/72-dc23

LC record available at https://lccn.loc.gov/2021016604

A British Cataloging-in-Publication record for this book is available from the British Library.

Copyright $\left({ }^{\circ} 2022\right.$ by Valerie Chepp

All rights reserved

No part of this book may be reproduced or utilized in any form or by any means, electronic or mechanical, or by any information storage and retrieval system, without written permission from the publisher. Please contact Rutgers University Press, Io6 Somerset Street, New Brunswick, NJ 0890 I. The only exception to this prohibition is "fair use" as defined by U.S. copyright law.

References to internet websites (URLs) were accurate at the time of writing. Neither the author nor Rutgers University Press is responsible for URLs that may have expired or changed since the manuscript was prepared.

$\ominus$ The paper used in this publication meets the requirements of the American National Standard for Information Sciences-Permanence of Paper for Printed Library Materials, ANSI Z39.48-1992.

www.rutgersuniversitypress.org

Manufactured in the United States of America 
For Zavi 
